\title{
The Galombang Duo Baleh Dance from Local Tradition to the Performance of Creation Dance
}

\author{
Darmawati \\ Lecturer of Sendratasik FBS \\ Universitas Negeri Padang \\ Padang, Indonesia \\ miz_watii@yahoo.com
}

\begin{abstract}
Galombang Duo Baleh Dance becomes an in separable part of the life of the people of West Sumatra Pariaman used and function ed at certain times only in the event of custom, ceremonial social and as entertainment. In the development of performing arts, Galombang Duo baleh dance can not compete with modern performing arts and more innovative dance background. It's time to apply the development model of Galombang Duo Baleh Dance: from local tradition to aesthetic creations dance as marketl eader of art industry that can be worth selling to seize the entertainment industry arts industry and tourism industry sector and society economy in West Sumatra, especially society of Sintuk Padang Pariaman. The research method isqualitative and experimental. Qualitative research isused to inventory and analyze traditional dance competitions in the entertainment industry and experimental research isused to apply the development model of Galombang Duo Baleh Dance. In addition, this study uses a multidisciplinary approach to the sociology of dance and music anthropology, choreography (dancecreation) as well as a performance artistic performances approach. The first phase of the research activities is directed to thein flowing of Galombang Duo Baleh Dance forms that are less competitive and marginalized as art industry commodities. The second stage is planned to construct the shape and structure of the development model of Galombang Duo Baleh Dance.
\end{abstract}

Keywords — The Galombang Duo Baleh Dance, Local Tradition, and Dance Performance

\section{INTRODUCTION}

Dancing Galombang Duo Baleh is a dance tradition that grows, lives, and develops in society Nagari Sintuk (Sintuk Village), District Sintuk Toboh Gadang district Padang Pariaman province of West Sumatra. According to information, Galombang Duo Baleh dance has long been used by the people of Sintuk, and has been inherited from ancestors of the past to the present generation in Sintuk. Galombang Duo Baleh dance to the present can still be found its activity in the society of Sintuk.

Before the era of independence around the 1930s, Galombang Duo Baleh dance has become a culture for people in the area of Sintuk. Dancing Galombang Duo Baleh serves as a medium to greet guests, as in the event Alek nagari and the inauguration of new buildings as well as to glorify the respected guests in a traditional event. For the people of Galombang. Duo Baleh dance this has been entrenched until now, although the quantity of activity has started to decrease nowadays in the society of Sintuk.

According to Sudirman according to Sudirman, the form of arts and performance of Galombang dance consists of several aspects, namely as a dancer who moves to dance movements, marawa (Minangkabau tradition flag), carano bearer who acts as a marriage between two parts of the formation of dancers Galombang Duo Baleh . In addition, another carano carrier, is acting as a betel carrier that presents to guests, who were greeted by the dance of Galombang Duo Baleh. All actors of Galombang Duo Baleh dance (dancer, musician, and carano bearer) are male.

The concept of dance Galombang Duo Baleh can be seen in the form of the show, which consists of 12 dancers who divide in two formations (each consisting of 6 people) and based on the number of dancers that 12 people, then collectively the community of Sintuk and surrounding named this dance Namely Galombang Duo Baleh dance. The two groups that make up the formation like the safes perform the galombang motion in opposition, while the distance between the two groups is approximately 20 meters. The place of execution is on public streets around or near the location of parties or ceremonies.

Both groups of Galombang dance is a part of the party who plays as a guest or guest and the other party plays as the host or who awaits the entourage that came (guests who come). Both groups of Galombnag Duo Baleh dancers are facing each other by performing dance activities.

This art performance is accompanied by gandang tambua music (same as taboo music). The rhythm and dynamics of the music will always increase, ie, become faster and louder when the dancer's position in the opposite straight line formation draws closer. In principle, the motion of Galombang is the movement of the step, ie the direction of the dancers who stepped from each group always pointing forward. As the dancers 'position approaches, the music sounds faster and louder, in turn between the two dancers' groups to be divorced by laying down the marawa flag between the two dance groups and placing a carano between them. In the next episode the dancers stop doing dance moves and then the carano bearers presenting salamah langkok (complete 
betel) as the host party to the guests, as a mark of respect. For the next side the host brings guests to the place of ceremony or seating that has been provided.

Until now, the Galombang Duo Baleh dance is still in the community of supporters, but the show is rarely implemented because the event alek nagari and the inauguration ceremony of the building has also been very rarely implemented. Because of this incident, the Dance of Galombang Duo Baleh lost the opportunity to be used by the people of Sintuk, therefore the intensity of its performance is decreasing nowadays in the cultural life of the people of Sintuk.

Currently, dancers Galombang Duo Baleh dance can still be found by some people, but already aged not young anymore and even there are almost 70 years old. At the present time only two adult dancers are really capable or adept to perform the dance of Galombang Duo Baleh. Both dancers are used as role models or models (examples) during the performance of Galombang Duo Baleh dance for the two dance formations of Galombang Duo Baleh. In turn the other dancers just mimic every movement performed by the dancer who became the guide. This has an impact on the quality of dance performance Galombang Duo Baleh is not neat or rampak. The dancers' movements that follow the elders are not synchronized, resulting in less aesthetic dance performances.

The younger generation or juvenile nagari Sintuk does not seem very interested or has the interest and motivation to learn Galombang Duo Baleh dance. There have been efforts made by Tuo dance or dance elders (people who master the dance of Galombang Duo Baleh) teach it to the younger generation, but the results are not as expected. The problem is likely because the less attractive and very rare packaging of the dance is shown in the crowd, which affects the lack of opportunities for the younger generation to perform this dance in public, so they have less place to see their expressions and creativity, They lost their passion to learn Galombang Duo Baleh dance in the village of Sintuk.

In the concept of entertainment and tourism industry, Dancing of Galombang Duo Baleh is now not worth selling, that is, there is no renewal or innovation in its cultivation of tari, such as no varied motion development, floor composition, music arrangement, performance venue, and absence of fashion arrangement As well as newer makeup.

On the other hand now, the style that evolves in entertainment industry shows is the pop dance, the lightweight dance in appreciation, full of variations of motion and improvisation of dancers, harmony and glamor in music, dressing and fashion, as well as dynamic and neat packaging. This is the impact of globalization that has penetrated into various sectors of life in the middle of society, such as the presence of the entertainment industry and tourism sector in Indonesia in general and West Sumatra in particular, including Padang Pariaman region. For that need to be renewed or development of dance Galombang Duo Baleh, in order to face the competitive competition between traditional arts and artistic creations, which include modern art. The quality of performances, such as the development of arable or the development of performance forms, and the development of performing arts management is an important thing to be developed in the current Galombang Duo Baleh dance.

\section{METHOD}

This research is qualitative research. the method used is descriptive research method, and research instrument is the researcher himself as a key instrument, and equipped with interview guides and observation guidelines, as well as audio visual recording equipment. Data were collected through interview, observation, and literature review, and documentation of the subjects of this study.

This research was conducted in Sintuk village of Padang Pariaman, West Sumatera Province. Researchers choose informants with the criteria of understanding and understanding with the object of research, involved with the activities of Galombang dance artists, and knowing the customs problems of Sintuk, as well as mengetaui problems Galombang dance from various angles of view. To ensure the validity of data, researchers cross ceck with colleagues, and do tri angulation.

Data analysis is done by stages of collecting data, selecting data that is really related to research problems, presenting data, and test data and conclude the data. The data collected are qualitative data, ie data about the development and existence of Galombang dance in the village of Sintuk, then data about the existence of the main data to be analyzed.

\section{FINDING AND DISCUSSION}

Dancing Galombang Duo Baleh in the village (Nagari) Sintuk is part of traditional Minangkabau dance in Padang Pariaman region. Dancing Galombang Duo Baleh representing the values of Pariaman society life, also became the identity of the community Padang Pariaman. Speaking of Galombang Duo Baleh dance with all its uniqueness then the discussion will be within the scope of characteristic and behavior of Padang Pariaman society in particular and Minangkabau generally.

Society puts galombang Duo Baleh dance functions in addition to the social fabric as reinforcement, as well as complementary activities in various ceremonial rites, rituals, and entertainment, as well as a medium of expression and media presentation gratification of human intuition, all of which are included in the interests of communication. Seeing the usefulness or function of so much dance in the life of the people of Pariaman, including for entertainment. This can trigger or motivate people to manage dance as a source of industry work or as a product that has a selling point. For economic actors who have the spirit of art, they respond to this reality by treating dance as an industrial commodity, which is associated with entertainment and tourism in West Sumatra. 
Galombang Duo Baleh dance today should not live terkukung within the culture (Sintuk Padang Pariaman) and are only present in several events, namely Alek Nagari and the inauguration of the buildings around the area of Padang Pariaman, but the dance is necessary to develop innovative as industrial commodities Entertainment and tourism.

As Nasbahri Cauto and Indrayuda (2013: 89) say that an art will die if it is latched on by ancient thought, so that the art will not continue to grow. As a result such works of art will die and extinct. The art should not be enshrined or stuck in narrow thinking by custom, but let the art form develop according to the times. In turn, the art will continue to be used by the community.

Referring to Cauto and Indrayuda's views, it turns out that Galombang dance has been confined in the old customary concept. Dance in Pariaman both Galombang and Indang art are often in the confines of a very fanatical tradition society. On the one hand the dance or art will always be in accordance with the custom but on the other hand, the art is increasingly abandoned by the community. In fact the art of tradition is rarely used by people today in the area of Sintuk Pariaman (Darmawati, 2005: 45).

Galombang Duo Baleh dance as a performance object, consisting of motion and musical accompaniment and the variety and style of costumes. Many things can be developed into a new form of dance that is more valuable in the economic level. Galombang Duo Dance is a traditional dance that has a unique range of motion, the movement is done on the opposite positions in the concept of conflict or attack each attack (in terms of Minangkabau are welcome welcome).

In accordance with the usefulness of Galombang Duo baleh dance this is to welcome or greet the guests, then the show is held in the yard or on the street in front of the event party or the inauguration of something. The composition of the dancers group consists of two groups, each consisting of 6 dancers. The first group of line formations stood in front of the venue, while the other group faced the venue and the group was in front of the guest to be greeted. Overall movement is a forward step movement that is always repeated, until the two groups of dancers come closer and before shaking first by the flag carrier custom called marawa.

The dance performance of Galombang Duo Baleh is still in the traditional form and the procedure of implementation is still according to the old rules and has an arrangement consisting of elements, ie there are twelve dancers, there is a flag carrier (marawa), there is a carrier of carano pelerai and the carrier Carano filled with complete betel served to guests. The dance performance begins with a music sound of about 1 minute, and only begins dance moves by two groups of dancers facing distance. Before the dancers facing each other, the other actors are 2 carano holders and 1 flag holder, they can not move or just stand silently on the edge of the arena. Conditions in the implementation of dance performance Galombang Duo Baleh is a rule that has been accepted for generations since the past, which must be obeyed by the perpetrators to this day. The rules imposed in the system of dance performance Galombang Duo Baleh impact on the lack of selling point of the dance. This causes the saturation of consumers, because too complicated packaging. Therefore, it should from now Galombang Duo Baleh dance is packaged in practical and compacted all the rules. So the dance of Galombang Duo Baleh can be worth selling economically.

Dancing Galombang Duo Baleh is a communal expression that contains social meaning and has multifunctional. To perform the dance performance Galombang Duo Baleh must follow the rules that apply, such as the order of implementation that must be passed in accordance with the arrangement that has been established since the first and should not be exchanged form of the composition that contains various elements that all still according to the existing pattern. That is, there should be no change, either in the procedure of implementation or in the form of presentation. Based on this can be interpreted that the performance of dance Galombang Duo Baleh still in a very simple form, which is still in the category of plain or no touch of innovation.

The Galombang Duo Baleh Dance as a performing object is still in a very simple form consisting of several elements, such as: (1) a very simple dance movement and has little motive and is performed often repeatedly from beginning to end of the show, as well as every dancer move should Always follow the command or command of the teacher or the elders of the dance; (2) dancers and presenters of performances consisting of men only; (3) accompanied by music that feels monotonous, because the same continuous sound repetition and the perpetrator is also composed of men; And (4) the costumes used in the show are still very simple or there is no structuring and development, and the makeup has not been put on makeup as per the performances of dancers.

In Galombang Duo Baleh dance performances covered some supporting elements consisting of customary objects, such as carano and marawa flag. These objects presented by the performers are still in a realistic form, just as the marawa flag is held while standing still by the dancer before it is laid down or there is no apparent movement of motion. Until now the Galombang Duo Baleh dance in Sintuk Pariaman has not been touched by creative artists to become a performance art that is entertaining and has a selling point.

Galombang Duo Baleh dance movements based on martial arts movements, namely: 'snaking motion', 'step tigo', 'tapuak', and there is also a so-called 'step odor'. Based on observations, this so-called 'step-by-step' movement seems to be a repetition of the tigo action. So-called motion 'marandah' which forms the movement with a low body position like squatting. The motion of 'marandah' is done only for a moment (in one count) and immediately stands up again to initiate a stepping motion. Movements performed from start to finish in the Galombang Duo Baleh dance performance do not have a standard or definite motion sequence as it has been compiled or predefined. However, Galombang Duo Baleh dance performance as a whole has a structure that is at the beginning of the dance begins with the motion 'sambah', then in the middle of the motion of 'step' (step tigo by the dancers who act as the host and sideline steps by the dancers who Guest role).

The structure or composition of dance movement Galombang Duo Baleh still has not changed. The current reality of Galombang dance has not received serious attention from the public. If there has been no change or intervention of creative artists 
and academic interventions to the Galombang dance structure, then Galombang Duo Baleh dance will be forgotten and abandoned by society, society will not use it again in various customs and ceremonies of government. Because the dance is considered not adjust to the condition of the development of performance art today in Indonesia or West Sumatra. Therefore, it is rare today that the people of Sintuk use Galombang Duo Baleh dance in various custom events.

A performing arts needs to have changes that are relevant to the tastes of the people. The performing arts will shift from its roots in the form of performances. Tardisi art will shift meenajdi art that is provan. This means that the art of tardisi will be used when the art has been transformed from tradition or ritual to the performing arts (Darmawati, 2007). Therefore, the issue of dance Galombang Duo Baleh can be overcome by the artist's creativity intervention.

With the many problems contained in Galabuhan Duo Baleh dance making this dance is rarely used by the people today. The weakness of this dance lies in its packaging that has never been updated to the taste of today's society. Both motion, music and costumes have not been developed or modified in the new form.

According to Indrayuda (2013: 76) that a performance art become used or diguanakn by society one of them must always follow the public taste. This means that the performing arts deserve to be enjoyed ati by the community based on the tastes of the community. Thus, the dance needs to be repackaged so that the uniqueness of dance Galombang Duo Baleh will be more interesting to watch and enjoyed by the community.

Entering the era of 2016, gradually people began trying to civilize back Galombang Duo Baleh dance in the area of Sintuk. Therefore, there should be an effort to improve the aspects of motion, music, costumes and performance procedures, so that Galombang Duo Baleh dance gets another chance to be used by Sintruk society as a proper dance for sale as an entertainment commodity.

As a unique dance tradition, it is fitting that there should be revamping. Reformation is seen from aspects of arable that need to be packaged properly in order to become a performance art work worth selling. Because if the Galombang dance is still bertyahan with the old form, then the dance Galombang Duo baleh akan threatened extinction.

A traditional performing arts needs to be intervened by creative artists or by academic artists, so the art of tardisi such as Galombang Duo Baleh dance can be transformed from rigid and standard tardisi to the art of entertainment that can better suit the tastes of today's society. Therefore, Galombang dance creations are an offer that should be done by traditional artists in Sintuk to transform Galombang Duo Baleh dance into a valuable creations dance. This knowledge and innovation intervention is an appropriate way to fix the packs of Galombang dance that are yet to be sold in the context of today's tourism and entertainment.

As Indrayuda (2015) says, that traditional dance art that has long been abandoned by the community, needs to be done pembenahan or intervention by academics. This means that traditional dances such as Galombang Duo Baleh dance need to be improved in terms of structure, floor design, performing procedures, movements and music and costumes, in order to produce an innovative dance art. The impact of the dance art of Galombang Duo Baleh is its selling point and its usefulness value. The point is that Galombang dance will increase its bargaining value by consumers.

Furthermore Indrayuda (2014: 123) said that Minangkabau traditional dance in various cities in West Sumatra, rarely become the entertainment consumption of travelers and entertainment community art lovers. However, it is a new dance that is rooted in Minangkabau dance, and people outside West Sumatra call it Minangkabau dance. The dances frequented by travelers are dance creations that have developed newer and more innovative forms. This means that the structure of the work is not patterned on the old tradition, but has experienced the process of creativity development. The fact is that this dance has undergone the intervention of coregraphic knowledge, so it is packed with attention to the laws of modern performing arts.

Therefore, whenever Galak Duo Baleh dance wants to continue to be used by the community, then indirectly must be addressed from the aspects of motion, music, costumes, performance procedures and properties. This means that the dance of Galombang Duo Baleh needs to be intervened by the knowledge of choreography, so that the dance becomes an innovative dance packaging. So in turn Galombang Duo Baleh dance became a popular dance in the area of Sintuk and Pariaman generally.

As Waruwu $(2015,35)$ says that the current Galombang dance is the Galombang dance that has undergone form transformation. This means that the current form of Galombang dance is no longer too embracing silat movement that many elements of conflict, but has turned into a Galombang dance that combines elements of tenderness and agility. Therefore, Galombang dancers today are not only men, but have many women as dancers, even carano bearers.

Referring to the explanation from Waruwu above, it turns out that Galombang dance is widely used by the community is the dance of Galombang creations, so that the aspects of the form and performers of Galombang dance have been transformed. Thus, for Galombang Duo Baleh dance to be a popular art used by people in Pariaman or in Sintuk, the Galombang Duo Baleh dance needs to be packed with innovation, so it will become more new and aesthetically and artistically.

Nerosti (2011: 18) says that Minangkabau dance has now changed from an established tardisi to entertainment art. Many people in urban areas use creations that are considered newer and more able to satisfy the artistic taste of the community. Therefore, the art of tardisi dance needs to be packed from various aspects in accordance with the taste of today's society. Galombang dance generally in West Sumatra has now changed. The urban community has used Galombang dance much more than the village community, but the Galombang dance they use is Galombang dance creation. 


\section{CONCLUSION AND RECOMMENDATION}

The traditional dance of Galombang Duo Baleh is now declared to be inadequate for use in guest reception in various ivent. Because the Galombang dance does not meet the criteria of the entertainment industry as it still has: (1) motion that is only one color and not developed, (2) the homogeneous culprit is only composed of men only, (3) supporting elements, / Customary objects (marawa flags, carano still plain (unadorned) and presentation realistically, and (4) following old rules that seem rigid.

To achieve the goals of the entertainment industry of Galombang Duo Baleh dance needs to be addressed with various interventions. One of the interventions is the tillage pattern, the motive shape of the motion, the costumes, the makeup and the music, as well as the performance procedure. Dancing Galombang Duo Baleh needs to be strived to develop in an innovative form, so the packaging becomes attractive artistic, and aesthetic. In turn the Galombang Duo Baleh dance can become popular and worth selling. The creative process has changed the shape of Galombang Duo Baleh dance packaging as a dance of presentday Galombang creations in Pariaman.

\section{References}

Darmawati. (2005). "Perubahan Fungsi Indang di Toboh Mesjid Balai Senayan Pauh Kambar Kabupaten Padang Pariaman". Padang: Lemlit UNP.

. (2007). “Tari Payung Padang Magek Batu Sangkar Kabupaten Tanah Datar”: dari Ritual ke Totonan Profan.

Indrayuda, I. (2015). Continuity of Tradition Dance: Acedemicians' Intervention on Artists and Performing Arts Groups. Harmonia: Journal of Arts Research and Education, 15(2).

Indrayuda, I. (2014). Poblematika Tari Minangkabau dalam Dinamika Pertunjukan Industri Hiburan. Humanus, 13(2), $123-134$.

Indrayuda. (2007). “Tari Minangkabau: Peran Elit Adat dan Keberlangsungan”. Padang : Lemlit UNP.

Indrayuda. (2008). “ Orientasi Spirit Tradisi dalam Karya Tari Kontemporer”. Jurnal Bahasa dan Seni. Vol. 9 Nomor 1 maret 2008.

Indrayuda.. (2009). "Peran Elit Adat dalam Keberlangsungan Tari Minangkabau". Jurnal Pendidikan dan Kebudayaan Balitbang Depdiknas Jakarta. Vol. 15 Nomor 2 Maret 2009.

Indrayuda. (2011). "Cultural Development in Minangkabau Dance Through The Effect of social Politics in West Sumatera (Perkembangan Budaya Tari Minangkabau dalam Pengaruh Sosial Politik di Sumatera Barat) “. Disertasi pada Universiti Sains Malaysia.

Cauto, Nasbahri dan Indrayuda. 2013. Pengantar Sosiologi Seni. Padang: UNP Press.

Nerosti. (2011). “Perubahan Tari Minangkabau dalam Masyarakat Perkotaan di Sumatera Barat”. Tanjung Malim : Universiti Pendidikan Sultan Idris Malaysia.

Susmiarti. (2009). "Fenomena Karya Tari Mahasiswa Sendratasik FBSS UNP”. Padang : FBSS UNP.

Zora Iriani. (2011). "Karya Tari Syofiani: Antara Gaya Melayu dan Gaya Sasaran. Padang : Lemlit UNP. 